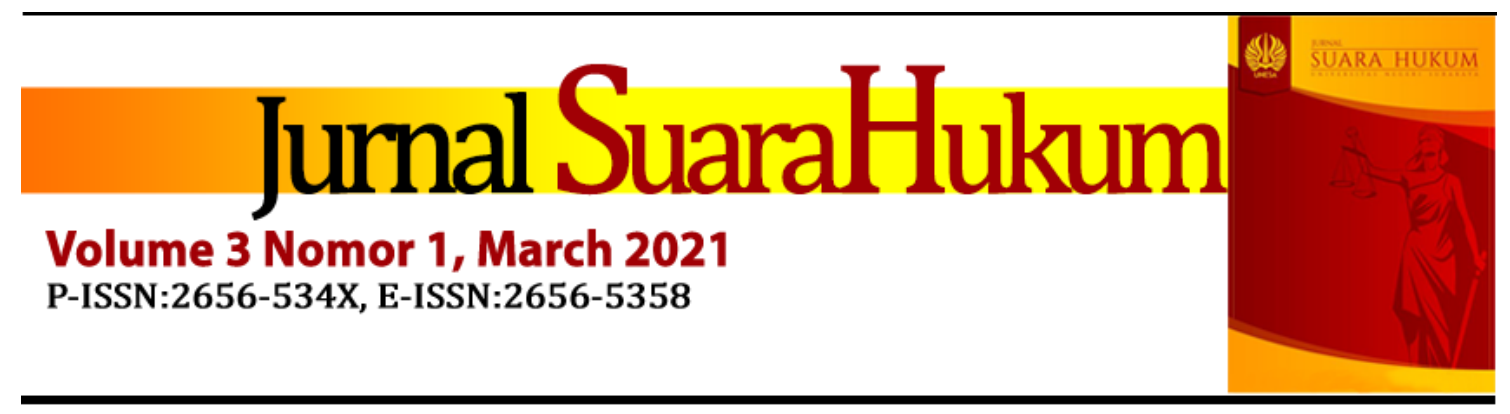

\title{
Problematik Kepastian Hukum Darurat Kesehatan Masyarakat Pada Masa Pandemi COVID-19
}

\author{
Hananto Widodo ${ }^{1}$ dan Fradhana Putra Disantara ${ }^{2}$ \\ ${ }^{1}$ Fakutas Ilmu Sosial dan Hukum, Universitas Negeri Surabaya, Surabaya, Indonesia, \\ hanantowidodo@unesa.ac.id \\ ${ }^{2}$ Fakultas Hukum, Universitas Jember, Jember, Indonesia, \\ dfradhana@gmail.com
}

Article history:

Received: 3 February 2021 | Last Revision: 22 February 2021| Accepted: 24 February 2021

\begin{abstract}
The Covid-19 pandemic has prompted the government to issue several legal products, including PP No. 21/2020 and Keppres No. 11/2020. However, this step raises legal problems, considering that the government actually issued PP. 21/2020 beforehand which does not place the Keppres No. 11/2020 in the preamble section. The research method used in this research is a statute approach and a conceptual approach; by using primary and secondary legal materials. The urgency of this legal research is to examine the legal certainty of the Presidential Decree that was made before the PP which regulates the technicalities regulated in the Presidential Decree; and examining the form of legal certainty in the regulations regarding the procedures for determining and lifting public health emergencies. The result of this legal research is the determination of the health emergency status based on the Keppres No. 11/2020 has created legal uncertainty, because the PP regarding the procedures for determining and revoking the status of determining health emergencies must be enacted before Keppres No. 11/2020. It takes an ideal form of legal certainty in the future by harmonizing the danger state law or the formation of a danger state law such as the omnibus bill.
\end{abstract}

Keywords: State of Emergency Law, Public Health Emergency, COVID-19

\section{Abstrak}

Pandemi Covid-19 mendorong pemerintah untuk mengeluarkan beberapa produk hukum, diantaranya adalah PP No. 21/2020 dan Keppres No. 11/2020. Namun, langkah tersebut menimbulkan masalah hukum, mengingat pemerintah justru menerbitkan PP No. 21/2020 terlebih dahulu yang tidak menempatkan Keppres No. 
11/2020 dalam bagian konsideran. Metode penelitian yang digunakan dalam penelitian ini adalah statute approach dan conceptual approach; dengan menggunakan bahan hukum primer dan sekunder. Urgensi penelitian hukum ini adalah meneliti kepastian hukum atas Keppres yang dibuat terlebih dahulu sebelum PP yang mengatur mengenai teknis yang diatur dalam Keppres; dan meneliti bentuk kepastian hukum dalam aturan mengenai tata cara penetapan dan pencabutan darurat kesehatan masyarakat. Hasil penelitian hukum ini adalah penetapan status kedaruratan kesehatan berdasarkan Keppres No. 11/2020 telah menimbulkan ketidakpastian hukum, oleh sebab PP mengenai tata cara penetapan dan pencabutan status penetapan kedaruratan kesehatan harus ditetapkan terlebih dahulu sebelum Keppres No. 11/2020. Di perlukan bentuk kepastian hukum yang ideal di masa mendatang dengan melakukan harmonisasi terhadap undang-undang keadaan bahaya atau pembentukan undang-undang keadaan bahaya seperti omnibus bill.

Kata Kunci: Kepastian Hukum, Hukum Kedaruratan Kesehatan, Pandemi Covid-19

\section{A. PENDAHULUAN}

Pandemi Coronavirus Disease 2019 (Covid-19) telah mengubah tatanan kehidupan masyarakat; baik di tingkat global maupun di tingkat nasional (Flood, MacDonnell, Philpott, Thériault, \& Venkatapuram, 2020). Pandemi Covid-19 memang merupakan sesuatu yang tidak konkrit, oleh karena Covid-19 sebagaimana virus lainnya merupakan sesuatu yang tidak terlihat, tetapi dampak dari penularannya sangat luar biasa. Sejatinya, dampak penularan Covid-19 membutuhkan tindakan dari pemerintah agar penularannya tidak semakin masif (Ewing, 2020). Tindakan pemerintah dalam menanggulangi dampak dari penularan Covid 19 ini merupakan kebijakan yang harus dituangkan dalam suatu aturan tertulis (Disantara, 2020d).

Penuangan suatu kebijakan pemerintah dalam aturan tertulis merupakan konsekuensi dari asas negara hukum (Sinnott, 2020). Secara konstitusional, Indonesia merupakan negara hukum sesuai dengan Pasal 1 ayat (3) Undang Undang Dasar Negara Republik Indonesia Tahun 1945 (UUD NRI 1945) (Disantara, 2020b). Menurut Mahfud MD (Moh. Mahfud MD, 2014), terdapat perbedaan yang cukup signifikan antara konsep 
negara hukum menurut UUD NRI 1945 sebelum perubahan UUD NRI 1945, dan setelah perubahan UUD NRI 1945. Perbedaan antara konsep negara hukum sebelum dan sesudah perubahan UUD NRI 1945 tidak hanya terletak pada pengaturannya semata; yang telah kita ketahui pada sebelum perubahan UUD NRI 1945 diatur dalam Penjelasan dan setelah perubahan UUD 1945 diatur dalam pasal-pasal dalam UUD NRI 1945.

Perbedaan konsep negara hukum sebelum dan sesudah UUD NRI 1945 terletak pada istilah yang digunakan. Pada UUD NRI 1945 sebelum perubahan UUD NRI 1945, istilah negara hukum menggunakan istilah rechtsstaat sebagaimana diatur dalam Penjelasan UUD NRI 1945 yang menyatakan bahwa Indonesia adalah negara hukum (rechtsstaat) bukan negara kekuasaan (machtsstaat); sedangkan dalam UUD NRI 1945 setelah perubahan tidak menggunakan istilah rechtsstaat. Konsep negara hukum setelah perubahan UUD NRI 1945 yang tidak menggunakan istilah rechsstat mengandung konsekuensi; bahwa konsep negara hukum setelah perubahan tidak lagi menganut negara hukum dalam tradisi Eropa Kontinental. Namun demikian, konsep negara hukum Indonesia setelah perubahan UUD NRU 1945 juga tidak menganut negara hukum dalam tradisi anglo saxon.

Mahfud MD juga menyatakan bahwa negara hukum Indonesia pasca perubahan UUD NRI 1945 menganut konsep prismatik (MD, 2012). Konsep prismatik dalam negara hukum merupakan konsep kombinasi atau jalan tengah di antara dua konsep negara hukum, yakni antara rechsstaat dan the rule of law. Sebagaimana diketahui, rechsstaat menekankan pada aspek kepastian hukum, sedangkan the rule of law menekankan pada aspek keadilan (Lucy, 2020). Dengan demikian, negara hukum Indonesia pasca perubahan UUD NRI 1945 di samping menekankan pada aspek kepastian hukum; juga mengacu pada aspek keadilan. 
Aspek kepastian hukum sangat terkait dengan perumusan suatu kebijakan dalam norma hukum, baik itu berupa keputusan (beschicking) dan peraturan (regeling) (Burgess, 2020). Sementara itu, aspek keadilan berkaitan erat dengan putusan pengadilan yang merupakan putusan terhadap pihak-pihak yang berperkara, apakah berdasarkan asas imparsialitas atau tidak (Palombella, 2020). Oleh karena itu, aspek keadilan biasanya selalu dikaitkan dengan proses beracara di pengadilan (Crisp \& Pummer, 2020). Kajian hukum tata negara dan hukum administrasi salah satunya adalah terkait dengan pengambilan keputusan oleh pejabat pemerintahan (Bell, 2020). Dalam mengeluarkan suatu keputusan, baik Presiden maupun pejabat publik lainnya, pasti akan mengacu pada peraturan perundang-undangan yang berlaku, baik pada level konstitusi maupun pada level peraturan perundang-undangan di bawahnya. Dasar hukum Presiden dalam mengeluarkan keputusan tentu juga memiliki landasan konstitusional karena dalam sistem presidensiil Presiden merupakan penanggungjawab tertinggi dalam pelaksanaan kekuasaan pemerintahan (Widodo, Prasetio, \& Disantara, 2020).

Persoalan pandemi Covid 19 dengan demikian juga merupakan tanggungjawab Presiden (Disantara, 2020c). Tanggungjawab di sini bukan diartikan sebagai tanggungjawab dalam artian pelaksana teknis, namun lebih pada tanggungjawab dalam pengelolaan negara secara umum (Disantara, 2020c). Oleh karena itu, jika mengkaji mengenai pandemi Covid 19 ini, maka terdapat beberapa aspek yang harus diatasi oleh pemerintah, karena pandemi Covid 19 ini tidak hanya berdampak pada aspek kesehatan saja, tetapi juga berdampak pada aspek lainnya, termasuk aspek ekonomi. Dasar hukum utama dalam mengatasi pandemi Covid 19 ini adalah Undang-Undang No. 6 Tahun 2018 tentang Kekarantinaan Kesehatan (UU Kekarantinaan Kesehatan) (Disantara \& Prasetio, 2020). Dalam UU Kekarantinaan Kesehatan tersebut, salah satu isu yang paling menarik 
adalah terkait dengan kondisi darurat kesehatan. Sebagaimana diketahui dalam hukum tata negara terdapat kajian mengenai hukum tata negara darurat (staatsnoodrecht) (Ackerman, 2020). Hukum tata negara darurat juga terdapat landasan konstitusionalnya dalam UUD NRI Tahun 1945.

Paling tidak terdapat dua landasan konstitusional hukum tata negara darurat dalam UUD NRI 1945, yakni Pasal 12 dan Pasal 22 (Disantara, 2020f). Pasal 12 UUD NRI 1945 mengatur mengenai negara dalam keadaan bahaya, sedangkan Pasal 22 UUD NRI 1945 mengatur kewenangan Presiden dalam mengeluarkan Perppu. Pasal 12 UUD NRI 1945 memerintahkan pada pembentuk undang-undang untuk membentuk undang-undang tentang syarat-syarat keadaan bahaya. Keadaan bahaya diatur dalam UndangUndang/Prp/No. 23 Tahun 1959. Jika dilihat pada tahun berlakunya undang-undang ini; seharusnya dilakukan revisi, mengingat undang-undang tersebut lahir pada masa Orde Lama, sehingga secara kontekstual undang-undang ini sudah tidak relevan dengan keadaan saat ini (Disantara, 2020a). Namun demikian, tidak berarti tidak ada upaya dari DPR untuk mengganti undang-undang ini. Pada tahun 2000, DPR dan Presiden sudah melakukan inisiasi untuk membentuk Rancangan Undang-Undang Penanggulangan Keadaan Bahaya (RUU PKB); hanya saja RUU PKB tersebut ditolak oleh publik karena dianggap terlalu represif. Penolakan publik terhadap RUU PKB kemudian direspon oleh Pemerintah dan DPR untuk tidak menindaklanjuti.

Penolakan publik terhadap RUU PKB di atas disebabkan karena kondisi yang terjadi di Indonesia, yang pada saat itu sedang memasuki masa transisi dari rezim otoritarian orde baru menuju rezim demokratik. Oleh karena itu, semua produk hukum yang dianggap memberi kewenangan yang luar biasa pada Presiden, akan mendapat tentangan dari publik. Penolakan dari publik yang cenderung reaksioner tidak bisa 
disalahkan begitu saja, oleh karena masyarakat masih trauma dengan Orde Baru yang cenderung menggunakan hukum untuk merepresi masyarakat, seperti undang-undang subversi. Konsekuensi dari tidak dilanjutkannya pembahasan RUU PKB untuk mengganti UU/Prp/No. 23 Tahun 1959 adalah tetap berlakunya UU/Prp/No. 23 Tahun 195. Dengan demikian, maka segala keadaan bahaya yang mengancam negara akan diberlakukan dengan undang-undang ini (Disantara, 2020a). Sepanjang masa pemerintahan Indonesia, mulai Orde Baru hingga sekarang, undang-undang ini tidak pernah diberlakukan.

UU/Prp/No. 23 Tahun 1959 akan diberlakukan oleh Presiden Jokowi untuk menanggulangi pandemi Covid-19 dengan cara menerapkan status darurat sipil, hanya saja oleh publik rencana tersebut mendapat tentangan. Pemerintah pada awalnya terkesan 'gamang' dalam menanggapi pandemi Covid-19, oleh karena baru kali ini sepanjang sejarah, Indonesia diuji dengan wabah penyakit berskala global. Sebelum Pemerintah pusat bertindak untuk menanggulangi dampak penularan dari Covid-19 ini, berbagai daerah-daerah sudah bergerak dulu untuk menanggulangi agar dampak penularannya tidak meluas (Disantara, 2020d). Setelah sekitar dua minggu pemerintah daerah bergerak sendiri tanpa koordinasi dengan Pemerintah pusat untuk menanggulangi dampak penularan Covid-19, baru Pemerintah pusat mengeluarkan beberapa produk hukum (Widodo, 2020c). Produk itu adalah Keputusan Presiden No. 11 Tahun 2020 Tentang Penetapan Kedaruratan Kesehatan Masyarakat Corona Virus Disease 2020 (Keppres No. 11/2020), Peraturan Pemerintah No. 21 Tahun 2020 tentang Pembatasan Sosial Berskala Besar Dalam Rangka Percepatan Penanganan Corona Virus Disease 2019 (PP No. 21/2020) dan Peraturan Pemerintah Pengganti Undang-Undang No. 1 Tahun 2020 tentang Kebijakan Keuangan Negara dan Stabilitas Sistem Keuangan untuk penanganan Pandemi Corona Virus Disease 2019 dan/atau dalam rangka Menghadapi Ancaman yang 
Membahayakan Perekonomian Nasional dan/atau Stabilitas Sistem Keuangan (Perppu No. 1/2020, yang akhirnya disepakati DPR dan Pemerintah untuk menjadi UndangUndang dan diundangkan menjadi UU Nomor 2 Tahun 2020).

Produk hukum di atas kemudian disusul dengan Peraturan Menteri Kesehatan No.

9 Tahun 2020 tentang Pedoman Pembatasan Sosial Berskala Besar Dalam Rangka Percepatan Penanganan Corona Virus Disesase 2019 (Permenkes COVID-19) dan Keputusan Presiden No. 12 Tahun 2020 tentang Penetapan Bencana Nonalam Penyebaran Corona Virus Disease 2019 Sebagai Bencana Nasional (Keppres No. 12/2020). Lahirnya Permenkes COVID-19 merupakan tindak lanjut dari PP No. 21/2020, sedangkan lahirnya Keppres No. 12/2020 merupakan tindak lanjut dari Undang Undang No. 24 Tahun 2007 tentang Penanggulangan Bencana Nasional, oleh sebab pandemi Covid-19 ini juga merupakan bencana non alam sebagaimana diatur dalam Undang Undang No. 24 Tahun 2007.

Berlakunya peraturan perundang-undangan yang mengatur tentang Pembatasan Sosial Berskala Besar (PSBB) semuanya didasarkan pada kedaruratan kesehatan yang ditetapkan oleh Presiden (Widodo, 2020b). Jika dilihat dalam konsideran 'mengingat' dalam PP No. 21/2020, memang tidak ditemukan Keppres No. 11/2020 sebagai dasar keberlakuannya. Akan tetapi, tanpa keluarnya Keppres No. 11/2020, maka PP No. 21/2020 tidak akan mungkin diterbitkan. Problematik status kedaruratan kesehatan masyarakat dalam Keppres No. 11/2020 juga terbilang unik, sebab ada pula undangundang yang mengatur tentang kedaruratan, meski dengan konteks yang berbeda. Kedaruratan kesehatan masyarakat juga dapat dikatakan baik secara normatif maupun secara teoritik mengalami ketidakjelasan, mengingat PP No. 11/2020 dan Permenkes COVID-19 secara substantif tidak mencerminkan sifat kedaruratan kesehatan 
sebagaimana dimaksud dalam Keppres No. 11/2020. Oleh karena itu, ke depan perlu dikembangkan pengaturan secara jelas mengenai kedaruratan kesehatan masyarakat.

Adapun dalam penelitian ini dapat dirumuskan sebagai berikut: 1) Apakah Keppres dapat dibuat terlebih dahulu sebelum PP yang mengatur mengenai teknis yang diatur dalam Keppres dibuat? ; 2) Apa bentuk kepastian hukum dalam aturan mengenai tata cara penetapan dan pencabutan kondisi darurat kesehatan masyarakat?

\section{B. METODE PENELITIAN}

Penelitian ini akan mengkaji kebijakan penetapan kedaruratan kesehatan masyarakat. Berdasarkan pada obyek penelitian yang akan diteliti, maka penelitian ini akan berpijak pada hukum positif. Obyek kajian yang dikaji dalam penelitian ini merupakan penelitian dalam bidang hukum tata negara. Atas dasar obyek penelitian di atas, maka jenis penelitian ini merupakan jenis penelitian normatif atau legal research. Penelitian hukum adalah suatu proses untuk menemukan aturan hukum, prinsip-prinsip hukum, dan doktrin-doktrin hukum guna menjawab isu hukum yang dihadapi (Marzuki, 2017). Penelitian ini menggunakan dua bahan hukum, yaitu bahan hukum primer dan sekunder. Hal ini sesuai dengan karakter preskriptif ilmu hukum. Penelitian hukum ini akan menggunakan dua pendekatan, yaitu : Pendekatan perundang-undangan dan Pendekatan konseptual. Pendekatan perundang-undangan dilakukan dengan menelaah semua undang-undang dan regulasi yang bersangkut paut dengan isu hukum yang diketengahkan (Susanti \& Efendi, 2015). Isu hukum yang diketengahkan dalam penelitian ini adalah kedaruratan kesehatan. Pendekatan perundang-undangan yang digunakan dalam penelitian ini dimulai dari UUD NRI Tahun 1945, UU No. 24 Tahun 2007 dan UU

No. 6 Tahun 2018. Pendekatan konseptual (conceptual approach). Pendekatan 
konseptual ini merujuk pada prinsip-prinsip hukum yang dapat ditemukan dalam pandangan-pandangan para sarjana hukum ataupun doktrin-doktrin hukum.

\section{HASIL DAN PEMBAHASAN}

\section{Kepastian hukum atas keppres yang dibuat terlebih dahulu sebelum pp yang mengatur mengenai teknis yang diatur dalam keppres}

Kajian mengenai kedaruratan negara, baik itu berupa darurat perang sampai dengan darurat kesehatan, maka akan selalu merujuk pada hukum tata negara darurat sebagai pijakan teorinya (Widodo, 2020c). Doktrin hukum tata negara darurat mengajarkan mengenai keadaan keadaan di mana norma-norma hukum tidak dapat diterapkan secara normal (Greene, 2020). Menurut Dullemen (Dullemen, 1947), terdapat empat syarat hukum tata negara darurat yang sah, yakni:

(a) Harus menjadi nyata bahwa kepentingan negara yang tertinggi menjadi taruhan, eksistensi negara bergantung pada dilakukannya tindakan darurat tersebut;(b) Tindakan itu sangat diperlukan dan tak bisa diganti tindakan lain; (c) Tindakan tersebut bersifat sementara (berlaku sekali atau dalam waktu pendek untuk sekadar menormalkan kembali); dan (d) Ketika tindakan diambil, parlemen tak dapat bersidang secara nyata. Maka dari itu, dalam keadaan normal, norma hukum dapat diberlakukan secara reguler, tetapi kadang-kadang, kurang terbayangkan akan ada keadaan lain yang bersifat tidak normal, tidak dapat diharapkan efektif untuk mewujudkan tujuan hukum itu sendiri (Asshiddiqie, 2008).

Keadaan darurat memberikan kemampuan negara untuk melaksanakan aspek keadilan melalui berbagai tindakan yang luar biasa dan bersifat sementara (Loevy, 2016). Pengambilan keputusan yang sangat tersentralisasi, penangguhan kontrol sosial atau demokrasi yang efektif, kebijakan kombinasi antara jangkauan 
pemerintahan dan administratif, pengesampingan kebebasan sipil, adalah beberapa ciri manakala penetapan status kedaruratan nasional dilakukan oleh pemerintah (Wiratraman, 2020). Terlebih, pada kasus Covid-19; sebagian besar negara memberi tanggapan hukum yang bersifat lebih memberikan batasan atas hak kebebasan masyarakat dan melakukan pembatasan yang sangat ketat pada aspek aktivitas kehidupan normal (Boughey, 2020). Pembatasan pada berbagai aktivitas ekonomi sosial, berkumpul, bergerak, digunakan untuk memperkuat pelayanan pada aspek medis; serta penangguhan berbagai hal administratif negara serta fiskal yang dijadikan sebagai cadangan negara untuk melindungi hak-hak sosial warga negara apabila terjadi keadaan yang sangat tidak memungkinkan (Gostin \& Hodge, 2020).

Penguatan pada aspek pelayanan medis tersebut ditunjukkan dengan menerbitkan pedoman protokol kesehatan, memanfaatkan tekanan moral dan sosial untuk mempromosikan kepatuhan terhadap praktik yang menjurus pada kesehatan pribadi masyarakat, menjaga jarak sosial, dan membatasi pertemuan publik. Biasanya, negara mewujudkan penetapan keadaan darurat melalui berbagai bentuk peraturan yang telah disesuaikan dengan konstitusi mereka. Bahkan, banyak negara memberikan kewenangan semi absolut kepada Presiden untuk mengambil alih kekuasaan yang luar biasa pada masa darurat (Cornell \& Salminen, 2018). Oleh karenanya, kondisi Covid-19 memandang bahwa negara dapat membuat suatu regulasi tanpa tindakan dari parlemen dan melakukan tindakan yang pada saat bermain tidak diizinkan untuk dilakukan (Effendi, 2020). Meskipun demikian, kesiapsiagaan pemerintah adalah hal yang patut diperhatikan manakala penetapan terhadap kesehatan dilakukan; oleh karena hal tersebut menyasar pada berbagai 
tindakan yang menjadi pelaksana suatu peraturan tentang penetapan darurat. Di sisi lain, kesiapsiagaan aparatur hukum dan instrumen hukum yang ada ada makan menjembatani adanya tindakan yang proporsional dan bertanggung jawab oleh aparatur hukum negara itu sendiri. Proporsionalitas tindakan hukum pada masa pandemi Covid-19 sangatlah penting; oleh karena pengambilan keputusan yang dilakukan tanpa memperhatikan keterbukaan dan aspek demokrasi hanya akan melemahkan institusi demokrasi dan budaya demokrasi partisipatif yang dapat mengakibatkan pula respon regulasi yang kacau dan tidak tepat (Tzevelekos \& Dzehtsiarou, 2020).

Keadaan tidak normal ini dapat merambah ke semua aspek kehidupan masyarakat, mulai dari darurat perang, darurat bencana sampai darurat kesehatan. Dalam keadaan tidak normal, maka penanganannya tidak bisa dengan cara normal, karena hukum positif yang dibentuk oleh negara secara umum digunakan untuk tujuan norma (Albert \& Roznai, 2020). Hukum positif, seperti Kitab UndangUndang Hukum Pidana (KUHP) memang dibentuk untuk mengatasi keadaan yang tidak tertib di masyarakat, seperti untuk menghukum seseorang yang terbukti membunuh orang lain. Namun demikian, terdapat perbedaan yang cukup mendasar antara ketidaktertiban masyarakat dan keadaan darurat negara. Paling tidak, ada tiga perbedaan antara ketidaktertiban masyarakat dan keadaan darurat negara, antara lain:

a. Ketidaktertiban masyarakat bisa diselesaikan dengan hukum positif biasa, seperti KUHP. Sedangkan keadaan darurat negara tidak bisa diselesaikan dengan hukum positif biasa; 
b. Ketidaktertiban masyarakat tidak bersifat meluas, sedangkan keadaan darurat negara bersifat meluas;

c. Ketidaktertiban masyarakat bisa diprediksi kapan berakhirnya dengan disertai upaya-upaya dari negara untuk menyelesaikannya. Sedangkan keadaan darurat negara tidak bisa diprediksi kapan berakhirnya meski disertai upaya-upaya dari negara untuk menyelesaikannya.

Menurut Kim Lane Scheppele, keadaan darurat adalah keadaan suatu negara yang sedang dihadapkan pada ancaman hidup-mati, sehingga membutuhkan tindakan responsif yang dalam keadaan normal tidak mungkin dapat dibenarkan menurut prinsip hukum (Scheppele, 2004). Oleh karena itu, Kasus Covid-19 tersebut merupakan konsekuensi daripada sarana konstitusional yang diwujudkan oleh pemerintah untuk memperlakukan suatu perbuatan hukum yang yang luar biasa atau tidak normal. Ketentuan darurat dalam konstitusi demokratis adalah antitesis terhadap hak yang dijamin secara konstitusional dan pengawasan dan keseimbangan kelembagaan, tetapi ketentuan tersebut diperlukan pada saat situasi darurat yang luar biasa dan keadaan darurat publik (Drinóczi \& Bień-Kacała, 2020). Masalah muncul ketika ketentuan darurat digunakan bukan sebagai tanggapan yang masuk akal terhadap keadaan darurat yang sebenarnya tetapi untuk memusatkan kekuasaan di tangan seseorang. Di sisi lain, penanganan krisis sebagaimana pada masa pandemi covid-19 oleh pemerintah melalui tindakan luar biasa adalah dalih yang masuk akal, mengingat tindakan tersebut bertujuan untuk mengendalikan atau mencegah penyebaran infeksi atau wabah/pandemi (Suganda \& Siregar, 2020). Bahkan, prinsip-prinsip hak asasi manusia pada masa tersebut sedikit tak dihiraukan. 
Elemen inti dari keadaan darurat adalah perlindungan holistik bagi seluruh warga masyarakat sebagai bentuk jaminan tanggung jawab negara untuk senantiasa memberikan aspek kenyamanan, keamanan, dan kesehatan (Drinóczi \& BieńKacała, 2020). Tak salah, apabila pemerintah memberikan kebijakan pemaksaan pemeriksaan medis, karantina individu, penahanan bagi para pelanggar protokol kesehatan, menara merdeka di rumah sakit, tidak melakukan aktivitas di sekolah, bekerja dirumah, dan lain sebagainya. Sekalipun begitu, kebijakan menahan diri memiliki berbagai banyak dampak positif; seperti mengurangi sumber daya beban administrasi publik pada badan publik, meningkatkan supremasi hukum dengan supremasi kesehatan, keselamatan publik, dan lain sebagainya (Tzevelekos \& Dzehtsiarou, 2020). Keadaan darurat mendorong negara untuk lebih intervensionis tanpa mengesampingkan kewajiban negara untuk menegakkan hak-hak dasar dan kebebasan, serta tanggung jawab moral kepada seluruh masyarakat. Maknanya, negara juga memiliki beban untuk memelihara kesejahteraan masyarakat melalui berbagai bentuk bantuan baik secara materi maupun non-materi (Sekalala, Forman, Habibi, \& Meier, 2020).

Negara harus memahami bahwa tidak diperkenankan menggunakan dalih pandemi untuk menjalankan kontrol sosial serta memberlakukan tindakan kan yang membungkam perbedaan pendapat, mengkriminalisasi oposisi politik, mempertahankan kekuasaan, dan mengkonsolidasikan kekuasaan (Albert \& Roznai, 2020). Meski penatapan darurat oleh suatu negara adalah respon dari adanya pandemi, kewenangan diskresioner pejabat publik harus dilakukan secara konsisten, efektif, bertanggungjawab, dan memperhatikan hak asasi manusia (Albert \& Roznai, 2020). Sehingga, penyusunan peraturan tentang keadaan darurat 
harus dapat diterima oleh masyarakat dan dianggap sah oleh masyarakat dengan memberikan pengetahuan atas batas-batas perilaku yang dapat diterima dari pemerintah pada masa darurat.

Konsekuensinya, masyarakat akan memahami serta menjalankan agar mereka dapat menghindari pelanggaran. Jikalau pemerintah tidak membuat peraturan hukum yang jelas dan komprehensif, bisa saja penerapan keadaan darurat justru akan menimbulkan kebingungan, perselisihan, konflik di antara masyarakat. Hal ini dipengaruhi dengan perbedaan interpretasi serta rekognisi dari masyarakat yang menyasar pada tindakan yang dilakukan oleh masyarakat itu sendiri untuk menghadapi kebijakan yang ditetapkan secara mendadak. Peraturan tersebut merupakan suatu Kerangka kerja yang menyasar pada tindakan individu pejabat publik untuk terus menjalankan kebijaksanaannya untuk menentukan suatu kebijakan yang harus dihadapi dan harus dilakukan pada masa pandemi covid-19 (Goldstein \& Suder, 2020). Harus dipahami, bahwa keadaan darurat identik dengan keadaan adanya risiko yang sangat buruk apabila tidak dilakukan dan dan adanya resiko kelambanan untuk menyelesaikan suatu masalah. Oleh karena itu, demi menyelamatkan negara dari ancaman serius negara terpaksa melakukan tindakan penyimpangan (Canestrini, 2020). Dengan demikian, kata kunci dari hukum tata negara darurat adalah pemberian kewenangan yang luar biasa kepada negara untuk segera menyelesaikan ancaman serius yang sedang dihadapi oleh negara. Hukum tata negara darurat yang merupakan teori yang melandasi keadaan darurat negara memiliki beberapa klasifikasi. Herman Sihombing menggolongkan hukum tata negara darurat ke dalam (Sihombing, 1996):

1. Hukum Tata Negara Objektif (Objectieve Staatsnoodrecht); 
2. Hukum Tata Negara Subjektif (Subjectieve Staasnoodrecht);

3. Hukum Tata Negara Tertulis (Geschreven Staatsnoodrecht);

4. Hukum Tata Negara Tidak Tertulis (Ongeschreven Staatsnoodrecht).

Menurut Jimly Asshidiqie, staatsnoodrecht dapat disamakan dengan hukum tata negara subyektif, sedangkan hukum tata negara obyektif diubah menjadi noodstaatsrecht (Asshiddiqie, 2008). Noodstaatsrecht subyek utamanya adalah staatsrecht atau hukum tata negara; sedangkan staatsnoodrecht subyek utamanya adalah keadaan darurat negara atau keadaan bahaya yang memberikan hak kepada negara untuk segera bertindak mengatasinya (Asshiddiqie, 2008). Pengertian secara mudah dari noodstaatsrecht atau hukum tata negara darurat obyektif adalah penguasa dalam melaksanakan kewenangannya untuk mengatasi keadaan darurat harus didasarkan pada syarat-syarat yang ditentukan dalam undang-undang. Sementara itu, staatsnoodrecht atau hukum tata negara darurat subyektif adalah penerapan keadaan darurat yang didasarkan pada penilaian subyektif penguasa. Kewenangan penguasa dalam menerapkan keadaan darurat berdasarkan penilaian subyektifnya dalam hukum administrasi dikenal dengan sebutan diskresi (Disantara, 2020e). Gayus T Lambunan mendefinisikan diskresi sebagai berikut (Yulikhsan, 2016):

"Diskresi adalah kebijakan dari pejabat negara dari pusat sampai daerah yang intinya membolehkan pejabat publik melakukan sebuah kebijakan yang melanggar undang-undang dengan tiga syarat, yakni demi kepentingan umum, masih dalam batas wilayah kewenangannya, dan tidak melanggar Asas-asas umum pemerintahan yang baik (AUPB)."

Dengan demikian, pada intinya diskresi merupakan penilaian dari pejabat pemerintah terkait dengan fakta yang dihadapinya (Biernat, 2020). Diskresi 
merupakan bentuk kewenangan dari pejabat pemerintah (Albert \& Roznai, 2020). Bentuk kewenangan dari pejabat pemerintah ada dua yakni yang berbentuk kewenangan terikat dan yang berbentuk kewenangan bebas (diskresi). Kewenangan terikat adalah kewenangan dari pejabat pemerintah yang di mana pemerintah tidak memiliki kewenangan melakukan penilaian karena semuanya syarat-syaratnya sudah diatur dalam peraturan perundang-undangan (Hadjon, 2019). Kewenangan bebas (diskresi) dari pejabat pemerintah ada yang bersifat bebas, tetapi ada juga yang bersifat terikat (Disantara, 2020f).

Diskresi bebas memberikan ruang para pejabat pemerintah untuk bebas mengambil keputusan apa saja, asalkan tidak melampaui atau melanggar batasbatas yang telah ditentukan oleh peraturan perundang-undangan. Sedangkan pada diskresi terikat, undang-undang menetapkan beberapa alternatif dan pejabat pemerintah bebas untuk memilihnya (Yulikhsan, 2016). Antara diskresi terikat dan kewenangan terikat pejabat pemerintah sekilas memang terdapat persamaan, tetapi pada hakikatnya keduanya merupakan hal yang berbeda. Dalam kewenangan terikat pejabat pemerintah, pejabat hanya benar-benar terikat pada peraturan perundangundangan tanpa ada kebebasan memilih. Contohnya pemberian SIM hanya dapat diberikan kepada pada warga negara yang telah berumur minimal 17 tahun. Sementara itu, dalam diskresi terikat, peraturan perundang-undangan memberikan memberikan beberapa alternatif untuk menyelesaikan masalah yang dihadapinya. Misalnya dalam penerapan sanksi administrasi, ada beberapa sanksi mulai teguran tertulis sampai pencabutan izin. Dalam penerapan sanksi ini, pejabat diberi kebebasan untuk menerapkan sanksi dengan cara memberikan teguran tertulis 
terlebih dahulu atau langsung dengan pencabutan izin sesuai dengan tingkat pelanggarannya.

Staatsnoodrecht merupakan kewenangan dari penguasa untuk menerapkan keadaan darurat negara, berdasarkan pada kewenangan diskresi dari penguasa, sedangkan noodstaatrecht merupakan kewenangan dari penguasa untuk menerapkan keadaan darurat negara, berdasarkan pada kewenangan terikat yang telah diatur dalam peraturan perundang-undangan, meskipun dalam noodstaatsrecht dimungkinkan adanya diskresi terikat dari penguasa. Implikasi hukum terhadap penetapan kedaruratan kesehatan masyarakat berdasarkan Keppres No. 11/2020 tidak dapat dilepaskan dari penerapan darurat kesehatan masyarakat; karena penetapan kedaruratan kesehatan masyarakan akan ditindaklanjuti dengan kebijakan Pemerintah untuk segera menyelesaikan masa darurat kesehatan masyarakat itu. Darurat kesehatan masyarakat ini dapat dilihat dalam dua konteks. Pertama, melihat pada siapa yang berwenang untuk menetapkan kedaruratan kesehatan. Pada konteks ini, penetapan darurat kesehatan dilakukan oleh Presiden, sehingga secara teoritik kedaruratan kesehatan termasuk dalam kajian hukum tata negara darurat. Kedua, melihat pada pengaturannya. Pengaturan kedaruratan kesehatan diatur dalam undang-undang kekarantinaan kesehatan; bukan undangundang keadaan bahaya. Sehingga, dari aspek pengaturan; kedaruratan kesehatan masuk dalam hukum kesehatan.

Merujuk pada ketentuan Pasal 10 ayat (4) UU Kekarantinaan Kesehatan yang berbunyi "Ketentuan lebih lanjut mengenai tata cara penetapan dan pencabutan sebagaimana dimaksud pada ayat (1) dan ayat (2) diatur dengan Peraturan Pemerintah"; seharusnya Pemerintah mengeluarkan Peraturan Pemerintah tentang 
tata cara penetapan dan pencabutan status kedaruratan kesehatan terlebih dahulu. Akan tetapi, Pemerintah justru mengeluarkan PP No. 21/2020 yang merujuk pada Pasal 60 UU Kekarantinaan Kesehatan. Pemerintah juga hanya mengeluarkan PP No. 21/2020 semata Padahal, dalam Pasal 60 UU Kekarantinaan Kesehatan bukan hanya PSBB yang harus diatur dengan Peraturan Pemerintah, tetapi juga tentang Karantina Wilayah, Karantina Rumah Sakit, dan Karantina Wilayah. Pengaturan terhadap persyaratan mengenai tata cara penetapan dan pencabutan status kedaruratan kesehatan melalui Peraturan Pemerintah ini menandakan bahwa secara ratio legis pembentuk undang-undang berkehendak agar terkait kedaruratan kesehatan masyarakat; menganut noodstaatrecht atau hukum tata negara obyektif. Implikasi hukum terkait penetapan status kedaruratan kesehatan berdasarkan Keppres No. 11/2020 telah menimbulkan ketidakpastian hukum, karena seharusnya secara normatif Peraturan Pemerintah mengenai tata cara penetapan dan pencabutan status penetapan kedaruratan kesehatan harus ditetapkan sebelum Keppres No. $11 / 2020$.

Implikasi hukum lainnya adalah terkait dengan penetapan kedaruratan kesehatan masyarakat yang tidak sinergis dengan pelaksanannya. Sebagaimana diketahui, ketika terjadi kedaruratan negara baik itu darurat sipil, militer, perang maupun darurat kesehatan masyarakat, maka langkah awal yang dilakukan oleh Presiden adalah menetapkan kedaruratan itu terlebih dahulu. Setelah Presiden menetapkan kedaruratan kesehatan, seharusnya Presiden melakukan langkahlangkah agar keadaan darurat kesehatan akibat Covid 19 ini segera teratasi. Namun, yang terjadi justru penyelesaian terhadap pandemi Covid 19 ini tidak berbanding lurus dengan kedaruratan kesehatan masyarakat yang telah ditetapkan oleh Presiden 
(Nasruddin \& Haq, 2020). Paling tidak, ada dua instrumen hukum sebagai tindak lanjut terhadap kedaruratan kesehatan Covid 19; yakni PP No. 21/2020 dan Permenkes COVID-19. Pengaturan dalam Peraturan Menteri Kesehatan ini tidak mencerminkan apabila negara Indonesia sedang dalam masa kedaruratan kesehatan; oleh karena terdapat mekanisme persetujuan untuk daerah yang ingin menerapkan PSBB (Widodo, 2020a). Sehingga, mekanisme yang digunakan dalam Peraturan Menteri Kesehatan ini adalah mekanisme yang normal (dalam keadaan normal).

Status kedaruratan kesehatan masyarakat dengan instrumen hukum untuk mengatasi pandemi Covid-19 harusnya berbanding lurus. Meskipun dalam Pasal 59 ayat (1) UU Kekarantinaan Kesehatan, PSBB merupakan bagian dari respon kedaruratan kesehatan masyarakat, tetapi kenyataannya tidak demikian. PSBB bukan merupakan instrumen luar biasa dalam penanganan pandemi Covid 19. Hal ini dibuktikan dengan ketidaktaatan masyarakat terhadap aturan PSBB (Ivanka, 2020). Oleh karena itu, apabila Presiden berkehendak untuk menetapkan kedaruratan kesehatan, maka kebijakan yang dipilih bukan PSBB; tetapi karantina wilayah (lockdown), oleh karena dengan karantina wilayah inilah maka Pemerintah dapat bertindak luar biasa demi percepatan penghentian pandemi Covid 19 ini. Pemerintah dapat menerapkan sanksi yang berat bagi pelanggar karantina wilayah berupa sanksi pidana, sedangkan bagi pelanggar PSBB, Pemerintah hanya dapat memberikan sanksi administrasi (Widodo, 2020b).

\section{Omnibus Bill: Ius Contituendum kedaruratan kesehatan}

Pengaturan ke depan yang ideal terkait dengan kedaruratan kesehatan masyarakat perlu dilakukan demi tercapainya kepastian hukum dalam kedaruratan 
kesehatan masyarakat, sehingga tidak terjadi tindakan eksekutif yang tidak akuntabilitas (Boughey, 2020). Sebagaimana diketahui, meskipun secara teoritik, kedaruratan kesehatan masyarakat ini masuk dalam hukum tata negara darurat, tetapi secara pengaturan kedaruratan kesehatan masyarakat, tidak masuk dalam hukum tata negara darurat. Hukum tata negara darurat secara konstitusional diatur dalam Pasal 12 dan Pasal 22 UUD NRI Tahun 1945. Undang-undang yang mengacu pada Pasal 12 adalah Undang-Undang No. 23/Prp/1959 tentang keadaan bahaya; yang mengatur mengenai tiga kategori, yakni darurat sipil, darurat militer dan darurat perang. Berbeda dengan undang-undang No. 23/Prp/1959 tentang keadaan bahaya, UU Kekarantinaan Kesehatan memiliki konsep kedaruratan tersendiri.

Konsep kedaruratan kesehatan masyakat dalam UU Kekarantinaan Kesehatan merupakan bagian dari kekarantinaan kesehatan. Oleh karena itu, terdapat perbedaan secara pengaturan antara undang-undang keadaan bahaya dan UU Kekarantinaan Kesehatan. Adanya dua undang-undang mengenai kedaruratan juga tentu akan membuat kesulitan dalam hal praktiknya. Apalagi, ada undang-undang lainnya yang juga mengatur mengenai kedaruratan bencana non alam sebagaimana diatur dalam undang-undang penanggulangan bencana. Beberapa undang-undang yang mengatur mengenai materi muatan yang saling beririsan akan dapat memiliki implikasi yang cukup serius (Singhvi \& Gautam, 2020). Implikasi itu antara lain terkait dengan ketidak harmonisan undang-undang terkait dengan persoalan kedaruratan negara. Ketidakharmonisan hukum akan membuat ketidak pastian hukum yang juga berakibat pada kesulitan dalam praktiknya. Peraturan perundangundangan semuanya akan diarahkan pada praktik hukum (Singhvi \& Gautam, 
2020). Oleh karena itu, jika terjadi ketidakharmonisan hukum, khususnya terkait dengan kedaruratan negara dan apabila negara ini berhadapan lagi dengan kasus seperti pandemi Covid 19 ini, maka negara akan gagap lagi dalam mengatasinya. Pengalaman negara dalam menangani pandemi Covid 19 merupakan contoh nyata kegagapan negara dalam menghadapi bahaya yang disebabkan oleh pandemi Covid 19.

Peraturan Pemerintah tentang tata cara penetapan dan pencabutan kedaruratan kesehatan hingga kini belum terbentuk. Begitu juga dengan Peraturan Pemerintah lainnya. PP. No. 21/2020 juga mengandung kelemahan yang cukup fundamental. Paling tidak ada, terdapat tiga kelemahan dalam Peraturan Pemerintah ini. Pertama, Peraturan Pemerintah ini tidak mengatur secara detail mengenai PSBB. Seharusnya, sebagai pelaksana teknis dari undang-undang; Peraturan Pemerintah harus lebih detail dibandingkan undang-undang yang menjadi induknya. Kedua, judul dari Peraturan Pemerintah ini langsung menyebut Covid 19. Padahal, Peraturan Pemerintah tidak bersifat menetapkan; tetapi mengatur. Seharusnya, judul Peraturan Pemerintah lebih bersifat umum dan abstrak, misal Peraturan Pemerintah tentang Wabah Nasional atau judul lainnya yang bersifat umum. Ketiga, keluarnya Peraturan Pemerintah tentang Pembatasan Sosial Berskala Besar ini seharusnya juga dibarengi dengan keluarnya Peraturan Pemerintah tentang Karantina Wilayah, Karantina Rumah dan Karantina Rumah Sakit.

Kekurang-sigapan Pemerintah dalam menangani pandemi Covid 19 ini merupakan hal yang wajar, karena baru pertama kali ini Indonesia mengalami pandemi. Namun demikian, ada kebiasaan kurang baik dari Pemerintah yang ikut membuat negara kesulitan dalam menghadapi pandemi ini. Kebiasaan ini antara 
lain, Pemerintah kurang cepat dalam membentuk Peraturan Pemerintah sebagai pelaksana teknis undang-undang kekarantinaan kesehatan. Padahal UU Kekarantinaan Kesehatan itu sudah berlaku sejak 2018, tetapi Peraturan Pemerintah sebagai pelaksana teknis undang-undang ini baru dibuat ketika pandemi Covid 19 mulai merambah ke Indonesia. Pembentukan Peraturan Pemerintah yang terkesan tergesa-gesa dalam merespon pandemi Covid 19 akan berakibat pada cacatnya dari Peraturan Pemerintah ini.

Harmonisasi terhadap undang-undang tentang keadaan bahaya ini sangat mendesak untuk dilakukan, tetapi harmonisasi ini harus dilakukan secara hati-hati (Fitryantica, 2019); karena pengaturan mengenai keadaan bahaya ini berpotensi untuk merepresi hak-hak dasar warga negara, sebab dalam undang-undang keadaan bahaya ini akan memberikan kewenangan yang sangat besar bagi penguasa untuk mengatasi keadaan bahaya ini (Goldstein \& Suder, 2020). Ketika penguasa melakukan upaya luar biasa dalam mengatasi keadaan bahaya ini, maka akan sangat berpotensi terhadap pelanggaran hak dasar warga negara (Thomson \& Ip, 2020). Oleh karena itu, harmonisasi undang-undang keadaan bahaya ini jangan sampai membuat gejolak di publik, sebagaimana omnibus bill UU Cipta Lapangan Kerja. Pembentukan undang-undang keadaan bahaya yang bersifat omnibus bill bukan saja perlu dilakukan secara hati-hati karena berkaitan dengan potensi penggunaan yang besar dari penguasa, tetapi juga perlu dilakukan secara cermat. Kecermatan pembentuk undang-undang omnibus bill keadaan bahaya ini perlu dilakukan karena bentuk keadaan bahaya ini merupakan sesuatu yang tidak dapat diprediksi tetapi dapat datang secara tiba-tiba. Oleh karena itu, omnibus bill undang-undang keadaan bahaya harus bisa mengantisipasi bahaya apa saja yang kemungkinan mengancam 
negara ini dan kewenangan apa saja yang dimiliki oleh penguasa agar keadaan bahaya ini dapat segera diatasi.

Perlu diketahui, Omnibus Bill merupakan rancangan dan/atau sebuah pengaturan untuk, oleh, dengan, dan dari segalanya yang mencakup hal-hal yang saling berkaitan (Chandranegara, 2020). Omnibus Bill dapat dikatakan pula adalah upaya untuk mencabut, mengubah, atau memberlakukan beberapa Undang-Undang yang memiliki sejumlah bagian yang terkait tetapi terpisah dengan bertujuan atas prinsip percepatan Penanganan dan percepatan tindakan. Orientasi dari pada omnibus Bill adalah membuat suatu peraturan dengan lebih efisien; dengan mengelompokkan bersama seputar topik tertentu yang memiliki bahasan satu subjek saja (Sembiring, Fatimah, \& Widyaningsih, 2020). Oleh karenanya, seringkali Omnibus Bill disusun secara cepat (dalam waktu yang singkat) dan menjangkau ratusan bahkan ribuan halaman. Omnibus Bill dianggap sebagai taktik pemerintah untuk menyelipkan perubahan substansial dalam aspek faktual yang di legitimasi melalui bentuk peraturan perundang-undangan yang memuat lebih dari satu hal substantif. Bahkan, Krutz berpendapat bahwa Omnibus Bill adalah cara bagi pembuat undang-undang untuk menggabungkan banyak proposal undangundang serupa di satu tempat yang menjadi paket perubahan kebijakan dari pemerintah setempat (Krutz, 2001). Pada masa darurat, hal tersebut sangat dimungkinkan mengingat membutuhkan kecepatan penanganan; agar penanganan pandemi memiliki dasar legitimasi dan memiliki perlindungan atas hak dan kewajiban baik bagi seluruh pihak.

Paling tidak, ada tiga alasan untuk melakukan harmonisasi terhadap undangundang keadaan bahaya. Pertama, Undang-Undang/Prp/No. 23 Tahun 1959 sudah 
terlalu lama; sehingga secara sosiologis pasti telah kehilangan daya berlakunya. Di samping itu, undang-undang ini dibentuk pada masa Orde Lama yang bercorak otoriter; sehingga undang-undang ini merupakan produk hukum yang represif. Kedua, ada beberapa undang-undang yang mengatur mengenai kedaruratan; yakni undang-undang keadaan bahaya, UU Kekarantinaan Kesehatan dan undang-undang penanggulangan bencana. Setiap undang-undang tersebut memiliki leading sector dalam menangani persoalan mengenai kedaruratan. Undang-undang kekarantinaan kesehatan leading sectornya berada di Kementerian Kesehatan, sedangkan Undangundang penanggulangan bencana leading sectornya berada di Badan Nasional Penanggulangan Bencana. Jika terdapat banyak leading sector, maka bisa berakibat pada miss-koordinasi dan tumpang tindih tupoksi terkait dengan penanggulangan keadaan bahaya. Pengalaman dalam menangani pandemi Covid 19 ini merupakan contoh nyata di mana tidak terjadi koordinasi yang sinergis antar instansi pemerintahan. Contoh paling nyata adalah ketika Gugus tugas percepatan penangan Covid 19 mengatakan tentang larangan mudik; tetapi Menteri Perhubungan malah membuka bandara. Begitu juga koordinasi antara pemerintah pusat dan pemerintah daerah yang kurang berjalan dengan baik. Ketiga, terkait tata cara penetapan dan pencabutan keadaan darurat harus diatur dengan undang-undang; oleh karena materi muatan dari undang-undang ini antara lain akan merampas hak dasar warga negara. Oleh karena itu, pengaturan tentang tata cara penetapan dan pencabutan kedaruratan kesehatan melalui Peraturan Pemerintah sebagaimana diatur dalam Pasal 10 ayat (4) UU Kekarantinaan Kesehatan adalah kurang tepat; oleh karena tata cara penetapan dan pencabutan kedaruratan kesehatan masyarakat merupakan materi muatan undang-undang. Namun demikian, lebih tidak tepat lagi jika 
kedaruratan kesehatan masyarakat ditetapkan oleh Presiden hanya didasarkan pada kewenangan diskresi sebagaimana Keppres No. 11/2020.

Dalam penentuan status kedaruratan baik itu darurat perang, sipil, militer serta kedaruratan kesehatan masyarakat, dan kedaruratan bencana, sejauh mungkin agar dihindari penetapan oleh penguasa yang didasarkan pada kewenangan diskresi semata. Penetapan status kedaruratan yang didasarkan pada kewenangan diskresi penguasa akan sangat riskan dengan tindakan sewenang-wenang dan penyalahgunaan wewenang yang berpotensi dilakukan oleh penguasa. Apalagi, dalam Pasal 49 UU No. 5 Tahun 1986 tentang Peradilan Tata Usaha Negara (PTUN), semua keputusan tata usaha negara (KTUN) jika dalam keadaan darurat atau dalam keadaan bahaya tidak dapat diperiksa oleh Hakim PTUN.

\section{PENUTUP}

Implikasi hukum penetapan kedaruratan kesehatan masyarakat berdasarkan Keppres No. 11/2020 menimbulkan ketidakpastian hukum. Hal ini dikarenakan apabila ditinjau berdasarkan ketentuan Pasal 10 UU Kekarantinaan, PP mengenai tata cara penetapan dan pencabutan status penetapan kedaruratan kesehatan harus ditetapkan terlebih dahulu sebelum Keppres No. 11/2020. Di sisi lain, implikasi hukum lainnya yang timbul adalah terkait pelaksanaan yang tidak relevan atas penetapan status kedaruratan kesehatan masyarakat. Hal ini dikarenakan di dalam Permenkes COVID-19, terdapat mekanisme persetujuan oleh Menteri Kesehatan untuk daerah yang ingin menerapkan PSBB, yang mana hal tersebut mencerminkan situasi dalam keadaan normal. Maka dari itu, diperlukan suatu rumusan peraturan perundang-undangan terkait dengan kedaruratan kesehatan masyarakat agar tercapainya kepastian hukum bagi masyarakat. Harmonisasi 
undang-undang tentang keadaan bahaya (omnibus bill) harus segera dilakukan; dengan memperhatikan hak-hak dasar warga negara, mengingat dalam undang-undang tentang keadaan bahaya akan memberikan kewenangan yang sangat besar bagi penguasa. 


\section{DAFTAR PUSTAKA}

Ackerman, B. (2020). The Emergency Constitution. Journal of Constitutional Law, 1(Special Edition), 9-63.

Albert, R., \& Roznai, Y. (2020). Constitutionalism Under Extreme Conditions: Law, Emergency, Exception. Cham: Springer Nature.

Asshiddiqie, J. (2008). Hukum Tata Negara Darurat. Jakarta: Raja Grafindo Persada.

Bell, J. (2020). The Anatomy of Administrative Law (1st ed.). Oxford: Hart Publishing.

Biernat, T. (2020). On the Lawmaking Policy, Discretion and Importance of the Rule of Law Standards. Studia Iuridica Lublinensia, 29(3), 67. https://doi.org/10.17951/sil.2020.29.3.67-85

Boughey, J. (2020). Executive Power in Emergencies: Where is the Accountability? Alternative Law Journal, 45(3), 168-174. https://doi.org/10.1177/1037969X20950514

Burgess, P. (2020). The Rule of Lore in the Rule of Law: Putting the Problem of the Rule of Law in Context. Hague Journal on the Rule of Law, 12(2), 333-361. https://doi.org/10.1007/s40803-019-00096-0

Canestrini, N. (2020). Covid-19 Italian emergency legislation and infection of the rule of law. New Journal of European Criminal Law, 11(2), 116-122. https://doi.org/10.1177/2032284420934669

Chandranegara, I. S. (2020). Kompabilitas Penggunaan Metode Omnibus Dalam Pembentukan Undang-Undang. Jurnal Hukum Ius Quia Iustum, 27(2). https://doi.org/10.20885/iustum.vol27.iss2.art2

Cornell, A. J., \& Salminen, J. (2018). Emergency Laws in Comparative Constitutional Law - The Case of Sweden and Finland. German Law Journal, 19(2), 219-250. https://doi.org/10.1017/S2071832200022677

Crisp, R., \& Pummer, T. (2020). Effective Justice. Journal of Moral Philosophy, 17(4), 398-415. https://doi.org/10.1163/17455243-20193133

Disantara, F. P. (2020a). Aspek Imunitas Dalam Penanganan Corona Virus Disease 2019. Istinbath: Jurnal Hukum, 17(1), 65-82. https://doi.org/https://doi.org/10.32332/istinbath.v17i1.2049

Disantara, F. P. (2020b). Pancasila Juga Volksgeist, Tanya Kenapa ? In I. Ronaboyd \& F. P. Disantara (Eds.), Filsafat Hukum Pancasila (Suatu Kajian Filsafat, Hukum, dan Politik) (pp. 63-68). Jakarta Selatan: Kreasi Cendekia Pustaka.

Disantara, F. P. (2020c). Tanggung Jawab Negara Dalam Masa Pandemi Covid-19. Jurnal Cendekia Hukum, 6(1), 48-20. https://doi.org/http://doi.org/10.33760/jch.v6i1.262

Disantara, F. P. (2020d). The Large Scale Social Restrictions Policy For Handling The 
COVID-19 Pandemic. Jurnal Pembaharuan Hukum, 7(2), 128-141.

https://doi.org/http://dx.doi.org/10.26532/jph.v7i2.9429

Disantara, F. P. (2020e). The Legitimacy of Circular Letter in Handling COVID-19

Pandemic. Rechtsidee, 6(2), 1-10. https://doi.org/10.21070/rechtsidee.2020.6.645

Disantara, F. P. (2020f). The Validity of Rectors Circular Letter on the Covid-19 Pandemic. UNIFIKASI : Jurnal Ilmu Hukum, 7(1), 126. https://doi.org/10.25134/unifikasi.v7i1.2765

Disantara, F. P., \& Prasetio, D. E. (2020). Nalar Hagemonik Perppu COVID-19.

Drinóczi, T., \& Bień-Kacała, A. (2020). COVID-19 in Hungary and Poland: extraordinary situation and illiberal constitutionalism. The Theory and Practice of Legislation, 8(1-2), 171-192. https://doi.org/10.1080/20508840.2020.1782109

Dullemen, A. van. (1947). Staasnoodrecht en Democratie. Alphen aan den Rijn: N. Samson NV.

Effendi, B. (2020). The Constitutional Interpretation In State Of Emergency In Facing Public Of Health Emergency. Jurnal Transformasi Administrasi, 10(1), 67-79.

Ewing, K. D. (2020). Covid-19: Government by Decree. King's Law Journal, 31(1), 124. https://doi.org/10.1080/09615768.2020.1759398

Fitryantica, A. (2019). Harmonisasi Peraturan Perundang-Undangan Indonesia melalui Konsep Omnibus Law. Gema Keadilan, 6(3), 300-316. https://doi.org/https://doi.org/10.14710/gk.6.3.300-316

Flood, C. M., MacDonnell, V., Philpott, J., Thériault, S., \& Venkatapuram, S. (2020). Vulnerable: The Law, Policy and Ethics of COVID-19. Ottawa: University of Ottawa Press.

Goldstein, N. D., \& Suder, J. S. (2020). Application of state law in the public health emergency response to COVID-19: an example from Delaware in the United States. Journal of Public Health Policy, 1(1), 1-9. https://doi.org/10.1057/s41271020-00257-8

Gostin, L. O., \& Hodge, J. G. (2020). US Emergency Legal Responses to Novel Coronavirus. JAMA, 323(12), 1131. https://doi.org/10.1001/jama.2020.2025

Greene, A. (2020). Emergency Powers in a Time of Pandemic. Bristol: Policy Press.

Hadjon, P. M. (2019). Pengantar Hukum Administrasi Indonesia. Yogyakarta: UGM Press.

Ivanka, N. (2020). Large-scale Social Restrictions: What's Next? The Indonesian Journal of International Clinical Legal Education, 2(2), 201-214. https://doi.org/https://doi.org/10.15294/ijicle.v2i2.38324

Krutz, G. S. (2001). Tactical Maneuvering on Omnibus Bills in Congress. American Journal of Political Science, 45(1), 210. https://doi.org/10.2307/2669368 
Loevy, K. (2016). Emergencies in Public Law: The Legal Politics of Containment. Cambridge: Cambridge University Press.

Lucy, W. (2020). Access to Justice and the Rule of Law. Oxford Journal of Legal Studies, 40(2), 377-402. https://doi.org/10.1093/ojls/gqaa012

Marzuki, P. M. (2017). Penelitiam Hukum (13th ed.). Jakarta: Kencana.

MD, M. M. (2012). Membangun Politik Hukum, Menengakkan Konstitusi. Jakarta: PT. Raja Grafindo Persada.

Moh. Mahfud MD. (2014). Politik Hukum di Indonesia. Jakarta: Rajawali Pers.

Nasruddin, R., \& Haq, I. (2020). Pembatasan Sosial Berskala Besar (PSBB) dan Masyarakat Berpenghasilan Rendah. SALAM: Jurnal Sosial Dan Budaya Syar-I, 7(7). https://doi.org/10.15408/sjsbs.v7i7.15569

Palombella, G. (2020). The Abuse of the Rule of Law. Hague Journal on the Rule of Law, 12(2), 387-397. https://doi.org/10.1007/s40803-020-00140-4

Scheppele, K. L. (2004). Law in a Time of Emergency: States of Exception and the Temptations of 9/11. Journal of Constitutional Law.

Sekalala, S., Forman, L., Habibi, R., \& Meier, B. M. (2020). Health and human rights are inextricably linked in the COVID-19 response. BMJ Global Health, 5(9), e003359. https://doi.org/10.1136/bmjgh-2020-003359

Sembiring, R., Fatimah, I., \& Widyaningsih, G. A. (2020). Indonesia's Omnibus Bill on Job Creation: a Setback for Environmental Law? Chinese Journal of Environmental Law, 4(1), 97-109. https://doi.org/10.1163/24686042-12340051

Sihombing, H. (1996). Hukum Tata Negara Darurat di Indonesia. Jakarta: Djambatan.

Singhvi, A., \& Gautam, K. (2020). The Law of Emergency Powers: Comparative Common Law Perspectives. Singapore: Springer Nature.

Sinnott, G. (2020). CONSTITUTIONAL LAW AND THE LIMITS OF RAWLSIAN LIBERTY. Legal Theory, 26(2), 124-155. https://doi.org/10.1017/S1352325220000178

Suganda, A., \& Siregar, M. A. (2020). The Meaning and Development of State Emergency Laws Based on Constitution in the Indonesian Legal System. Proceedings of the 2nd International Conference of Law, Government and Social Justice (ICOLGAS 2020). https://doi.org/10.2991/assehr.k.201209.336

Susanti, D. O., \& Efendi, A. (2015). Penelitian Hukum. Jakarta: Sinar Grafika.

Thomson, S., \& Ip, E. C. (2020). COVID-19 Emergency Measures and The Impending Authoritarian Pandemic. Journal of Law and the Biosciences, 1(1), 1-64. https://doi.org/10.1093/jlb/lsaa064

Tzevelekos, V. P., \& Dzehtsiarou, K. (2020). Normal as Usual? Human Rights in Times of covid-19. European Convention on Human Rights Law Review, 1(2), 141-149. 
https://doi.org/10.1163/26663236-00102001

Widodo, H. (2020a). Adakah Istilah Pengetatan dan Pelonggaran PSBB dalam Aturan Hukum?

Widodo, H. (2020b). Antara Sanksi Administrasi dan Pidana dalam PSBB.

Widodo, H. (2020c). Kepastian Hukum Darurat Kesehatan.

Widodo, H., Prasetio, D. E., \& Disantara, F. P. (2020). Relasi Kekuasaan Antar Presiden dan Wakil Presiden dalam Sistem Ketatanegaraan Republik Indonesia. Pandecta Research Law Journal, 15(1), 13-25. https://doi.org/10.15294/pandecta.v15i1.24554

Wiratraman, H. P. (2020). Does Indonesian COVID-19 Emergency Law Secure Rule of Law and Human Rights? Journal of Southeast Asian Human Rights, 4(1), 306. https://doi.org/10.19184/jseahr.v4i1.18244

Yulikhsan, E. (2016). Keputusan Diskresi Dalam Dinamika Pemerintahan. Yogyakarta: Deepublish. 